\title{
THE ANALYSIS OF THE READING MATERIALS IN "ENGLISH ON SKY 2" TEXTBOOK BASED ON SCHOOL-BASED CURRICULUM FOR GRADE VIII STUDENTS OF JUNIOR HIGH SCHOOL
}

\author{
*Nurul Hidayah Siregar \\ **Masitowarni Siregar
}

\begin{abstract}
Siregar, Nurul Hidayah. 209321053. The Analysis of the Reading Materials in “English on Sky 2" Textbook Based on School-Based Curriculum for Grade VIII Students of Junior High School. A Thesis. Faculty of Languages and Arts. State University of Medan. 2016.
\end{abstract}

This study attempts to describe the conformity between reading materials in English on Sky 2 Textbook for grade VIII students' of junior high school and the requirements of School-Based Curriculum in the aspects of indicators, text types, social function, rhetorical structure, and linguistic features. It was designed as documentary analysis in the form of descriptive qualitative research. The data of this study were reading materials collected from English on Sky 2 Textbook published by Erlangga in 2007. Based on the analysis of those aspects, it was found that the aspect of indicators gains $81.66 \%$ conformity, the aspect of Text types gains $66.66 \%$ conformity as the six text types required by School-based Curriculum are not all presented in the textbook, the aspect of social function gains $37.5 \%$ conformity, moreover, the aspect of rhetorical structure gains $100 \%$ conformity, and the aspect of linguistic features gains $100 \%$ conformity. From the data obtained, the total conformity between the textbook and the requirements of School-based Curriculum attains $77.16 \%$ conformity. This number is categorized as good according to Nurgiyantoro's Criterion Referenced Evaluation. Therefore, this textbook is appropriate to be used by both teachers and students in English language teaching, particularly in teaching reading as this textbook has already followed the instructions and the requirements of Schoolbased Curriculum.

Key words: reading materials, textbook, School-based Curriculum

*Graduate Status

**Eecturer Status 


\section{INTRODUCTION}

\section{Background of the Study}

An analysis of the learning material is necessary to improve the teachinglearning process and to keep the teaching-learning process on the track of the curriculum. This aims at ensuring that the learning materials the students learn suit the demands of present curriculum and is compatible with their needs, interests, and level. In line with this, Richards (2001:15) points out that educational program should be based on an analysis of learners' need as one of fundamental assumption of curriculum development. It focuses on determining knowledge, skills, value, students learn in school, the students have to be provided with learning experience, and teaching-learning process in school or educational program that are required in the curriculum.

Present curriculum, School-based Curriculum (KTSP) notes four language skills, namely listening, speaking, reading and writing, that should be achieved by the students in learning English. Those four skills have their own different competence standards and School-based Curriculum requires the students supposingly to understand and to deliver various meanings (interpersonal, ideational, and textual) in the kinds of interactional verbal text for listening and speaking, or non-verbal text for reading and writing, and also monolog texts especially descriptive, narrative, spoof, procedure, report, forms (Balitbang Depdiknas, 2003:17). 
Dealing with the four skills, Brown (2004:185) claims that reading is arguably the most essential skill for success in all educational contexts. Yet, reading is one of the most complex skills that many learners still find difficulties and problems to acquire this skill. This is due to learning to read is a decontextualized activity that clearly presents linguistic and cognitive challenges for children that are somewhat separate from those presented during highly contextualized, spoken communication (Hoskyn, 2004:109).

There are many reasons affecting students' lack of reading skill; it may be their lack of reading strategies, their lack of word recognition and phonemic awareness, but major reason of this problem is that the reading material students read does not suit to their knowledge level, needs, and interests. Therefore, teachers who dominantly take responsibility in providing reading materials for teaching reading, need to select appropriate textbook to help their students succeed in acquiring reading skill. This is due to the fact that textbook is one of the most important teaching instruments teachers may use to enable students achieve the learning goals. In addition, it also functions as a daily guidance or instruction for the teacher (Posner, 2004:6).

However, the process of selecting an appropriate textbook is not a frivolous matter. Teachers should consider some aspects before determining a good textbook for the students. They should be making an informed decision which is based on detailed analysis of what it offers and what the students need. They also have to consider that a good textbook not only covers knowledge which should fit to the requirements and the demands of the curriculum, but also generates interests 
and motivation for the students who read it as the students tend to read something that is interesting for them. As the result, teaching and learning process can be purposeful and meaningful.

Therefore, English teachers have to be selective to find the proper textbooks in order to improve teaching and learning process, particularly in teaching reading. Because by selecting good textbook which features good reading materials, teachers can provide students knowledge to achieve learning goals and to increase their students' intellectuality which later has a big influence to their academic success.

To examine whether teachers have selected propers textbook, the reseacher conducted an early observation in second grade of SMP Swasta Bandung Deli Serdang. It was found out that the school only enables the teachers to select the textbooks if it is marked with "based on content standard". It was also found out that this school uses "English on Sky 2" textbook published by Erlangga. During the observation, the teacher argued that this textbook is relevant to School-based Curriculum standard, beside it is published by prominent publisher that they have been trusting for years, and most of all, it covers materials and knowledge students need in learning English. But these statements can not be completely taken for granted. Considering the condition above, the researcher was challenged to conduct a study on analysis of "English on Sky 2" textbook which is used by the second grade students of SMP Swasta Bandung Deli Serdang in aspect of reading materials which being examined to see its conformity to School-based Curriculum criterias. 


\section{REVIEW OF LITERATURE}

Reading is an activity in which readers respond to and make sense of a text being read connected to their prior knowledge (Spratt, et al., 2005:21). The activity is done by the readers as they want to get information and knowledge from the text. In the process of getting information and knowledge, the readers try to connect what they read in the form of written language to what they have already known about the text. Making sense of a text is done by understanding meaning of words, sentences, and even a text.

Material in reading classroom is arguably the most important aspect that will shape and seize the teaching and learning process. A good reading material has to promote lively interaction between students and teachers as well as among students themselves to achieve a communicative language learning process. Consequently, teachers need to put effort on creating materials that will live up to that expectation. In reality, however, most teachers do not have enough time to create their own materials that using textbook becomes the only remaining option. Then again, no textbook is designed for their students with their particular needs and characters that make teachers still need to wisely select and even modify textbook materials.

Nuttal (1996: 170-177) in his book point out some criteria in selecting text for good reading materials. They are; Suitability context, Exploitability of context, Readability of context, Variety of context. Authenticity of context

Teaching materials are key component in most language programs. Whether the teacher uses textbook, institutionally prepared materials generally 
serve as the basis for much of the language input learners receive and the language practice that occurs in the classroom. Some teachers use instructional materials as their primary teaching resource. For learners, materials may provide the major source of contact they have with the language apart from the teacher.

The materials are tool for a teacher in the teaching-learning process. It is something that can be presented and something that can be used for classroom activities. It provides the language elements such as grammar or list of vocabularies.

However, in school-based curriculum teaching reading materials for second grade of junior secondary school are: Descriptive text , Narrative text, Recount text, Invitation, Announcement, Short message

A medium is a means to help the teachers when the teaching and learning activities progress. A teacher usually uses some media to make him or her easier in explaining the teaching materials. One media which is ordinarily used is a textbook. The textbook is easy to buy, to carry, and to study. Even though there are so many kinds of media rivaling the printed materials of communication, the textbook remains the major source in school.

Textbook is a book giving instruction in a subject, used especially in schools, etc.According to Thomson, (2009:175) "the textbook is a stimulus or instrument for teaching and learning". In another definition, textbook is a manual of instruction or a standard book in any branch of study which is produced according to the demands of educational institutions. 


\title{
RESEARCH METHODOLOGY AND FINDINGS
}

\author{
Methodology
}

This study was conducted by applying descriptive qualitative research design. According to Ary, et al. (2010:29), qualitative research design is a holistic picture and depth understanding rather than a numeric analysis of data. Hence, the result of this study is described in the form of words rather than statistical calculation.

The data of this study were carried out by documentary or content analysis. Documentary or content analysis focuses on analyzing and interpreting recorded material to learn about human behavior. The material may be public records, textbooks, letters, films, tapes, diaries, themes, reports, or other documents (Ary, et al. 2010:29). In this study, the materials deals with textbook entitled English on Sky 2 published by Erlangga. The reading materials were collected from the textbook and then were analyzed to describe its conformity with the rquirements of School-based Curriculum.

\section{Techniques of Analyzing the Data}

There were some steps in this study analysis. The first was describing conformity between the indicators in the analyzed textbook and the indicators in the syllabus of school-based curriculum. The second was describing the conformity between the distribution of genre in the textbook entitled " English on Sky 2" to required genre in the syllabus of school-based curriculum. The third was describing the distribution of features of genre (social function, rhetorical 
structure, and linguistic features). The last was to gain the result percentage of those conformities.

To find out these data, the researcher used the descriptive analysis technique percentages which were calculated using this following formula:

$$
P=\frac{f}{n} \times 100 \%
$$

Where:

$\mathrm{P}$ : the percentage

f: the frequency (appeared in school-based curriculum)

$\mathrm{n}$ : the sum of frequency ( appeared in the analyzed textbook)

The researcher also used "Criterion Referenced Evaluation" as proposed by Nurgiyantoro to count how far the textbook develops the skill of reading materials that should be developed based on the School-based Curriculum.

\section{Criterion Referenced Evalution}

\begin{tabular}{|c|c|c|}
\hline No & Interval Percentage & Description \\
\hline 1 & $81 \%-100 \%$ & Very Good \\
\hline 2 & $61 \%-80 \%$ & Good \\
\hline 3 & $41 \%-60 \%$ & Fairly Good \\
\hline 4 & $21 \%-40 \%$ & Bad \\
\hline 5 & $0 \%-20 \%$ & Very Bad \\
\hline
\end{tabular}


Findings

The Total Conformity between the Textbook and School-based Curriculum

\begin{tabular}{|c|c|c|}
\hline No. & Aspect being Analyzed & $\begin{array}{c}\text { Percentage of } \\
\text { Conformity }\end{array}$ \\
\hline 1. & Indicators & $81.66 \%$ \\
\hline 2. & Text Types & $66,66 \%$ \\
\hline 3. & Social Function & $37,5 \%$ \\
\hline 4. & Rhetorical Structure & $100 \%$ \\
\hline 5. & Linguistic Features & $100 \%$ \\
\hline & Total Conformity & $\mathbf{7 7 . 1 6 \%}$ \\
\hline
\end{tabular}

After having analyzed the data, it can be known that some aspects do not achieve $100 \%$ conformity with the requirements of School-based Curriculum. In the syllabus indicators there are two indicators (to identify social function short functional and to identify social function of descriptive and recount text) for each indicator, there are only one short functional and two of Text types, so the percentage that could be found are around $37.5 \%$ (in the first semester and second semester). Then, the percentages of the indicators are $81.66 \%$ and the percentage of text type's gain $66.66 \%$. On the other hand, two of the aspects achive excellent percentage by gaining $100 \%$ conformity. Based on this analysis, it could be calculated that the total conformity of those aspect achieves $77.16 \%$ conformity. Based on Nurgiyantoro's Citerion Referenced Evaluation, this number is categorized as good. Therefore, the textbook is suitable to be used by the students for second grade of junior high school. This means that this textbook has already followed the instructions and the requirements of School-based Curriculum. 


\section{CONCLUSION AND SUGGESTIONS}

\section{Conclusion}

After analyzing the data and elaborating the findings, conclusion were drawn as following

1. The percentage of reading materials in English on Sky 2 textbook gains $77.16 \%$ conformity with the requirements of School-based Curriculum So, this textbook has good relevancy with School-based Curriculum.

2. The distribution of reading materials "English on Sky 2" textbook as follows: The analysis of indicators gain $75.71 \%$, text types $(66.66 \%)$, social function (37.5\%), generic structure (100\%) and linguistic features $(100 \%)$.

\section{Suggestions}

After having analyzed the textbook, some suggestions are pointed out to:

1. English Teachers

English teachers have responsibility in providing and facilitating students with good textbook. Therefore, they have to select good textbook which is suitable for their students. They have to considers many things regarding to their students' needs and the textbook's contents. 


\section{REFERENCES}

Anderson, Mark and Kathy, Anderson. 1998. Text Types in English. South Yarra: Macmillan Education Australia Pty Ltd.

Ary, D., et al. 2010. Introduction to Research in Education Eighth Edition. United State of America: Wadsworth Group

Brown, James Dean. 1995. The Elements of Language Curriculum. Boston: Heinle \& Heinle Publishers. Cambridge, Advanced Learner's Dictionary.

Bungin, Burhan. 2011. Penelitian Kualitatif. Jakarta: Fajar Interpratama.

Clarke, David F. 1989. Language Teaching: Communicative Theory and Its Influence on Materials Production, 22/02,p 73-86.

Depdiknas. 2006. Peraturan Pemerintah Republik Indonesia, No. 22 Tahun 2006 Tentang Standar Isi untuk Satuan Pendidikan Dasar dan Menengah. Jakarta: Depdiknas.

Hutchinson, Tom and Alan, Waters. 2002. English for Spesific Purpose: A Learning - Centered approach. Cambridge: Cambridge University Press.

Langan, John. 2000. College Writing Skills with Reading.Boston: McGraw-Hill.

Mulyasa, E. 2007. Kurikulum Tingkat Satuan Pendidikan. Bandung: Remaja Rosdakarya.

------------. 2007.KTSP SuatuPanduan Praktis. Bandung: Rosada.

Muslich, Mansur. 2009. KTSP Dasar Pemahaman dan Pengembangan. Jakarta: Bumi Aksara.

Nunan, David. 2003. Teacher's TextBook: Practical English Language Teaching. New York: McGraw Hill Companies Inc.

Posner, George J. 2004. Analyzing the Curriculum. New York: McGraw Hill.

Richards, Jack. 2001. Curriculum Development Language Teaching. Cambridge: Cambridge University Press. 
Silabus, Mata Pelajaran Bahasa Inggris Kelas VIII SMP SWASTA BANDUNG Kabupaten Deli Serdang.

Spratt, M., Pulverness and Williams, M. 2005. The TKT Course. Cambridge: Cambridge University Press.

Sudjono, Anas. 2010. Pengantar Statistik Pendidikan. Jakarta: Raja grafindo. 